\title{
B111 スクワット動作時における CR 型人工関節置捔膝の動態解析 Motion Analysis in Squat Activity for CR Type Artificial Knee Implants
}

\author{
○学 福島 辰巳 (九産大) 正 日垣 秀彦（九産大）正 下戸 健 (JST) \\ 正 中西 義孝 (九州大) 非 三浦 裕正 (九州大) 非 岩本 幸英（九州大）

\begin{abstract}
Tatsumi FUKUSHIMA, Kyushu Sangyo University, 2-3-1 Matsukadai, Higashi-ku, Fukuoka Hidehiko HIGAKI, Kyushu Sangyo University Yoshitaka NAKANISHI, Hiromasa MIURA and Yukihide IWAMOTO, Kyushu University
\end{abstract} \\ Takeshi SHIMOTO, Japan Science and Technology Agency
}

Key words: Total KneeArthroplasty, Image Matching, Flat Panel Detector

\section{1. 粕言}

超高路社会への移行に伴い，整形外科領域において関節り ウマチ (Rheumatoid Arthritis) や変形性膠関節症 (Osteoarthrosis) 等の疾患に対し，人工材料に置き換え生体関節が本来受け持 つ軸受けとしての関節機能を代替する全人工膝関節置換術 (Total Knee Arthroplasty, TKA) が多用されている. 現在，日 本国内において年間 4 万件以上施行されており，注目される 手術である. しかしながら, 膝関節の複雑な 6 自由度運動に 起因するポリエチレンインサートの摩耗が問題となっている. したがって, 日常生活動作時の人工関節置換膝の解析を行い, 大腿骨コンポーネントとポリエチレンインサートの相対関係 を明らかにすることで, 摩耗の問題が改善されると考えられ る. 動態解析の動作として，跍き運動，階段昇降，スクワッ 卜動作，および歩行等が対象として挙げられるが，スクワッ 卜動作時の動態解析はあまり行われていない，スクワット動 作は，しやがみ込んだり立ち上がったりする動作であるため， 日常生活で欠かせない動作の 1 つである. 動態を明らかにす ることで, QOL (Quality of life) の向上にも繋がると考えられ る. そこで本研究では, フラットパネルディテクター (Flat panel detector, FPD) から出力される医用画像とイメージマッチ ング法 (Image matching IM) を応用し，人工関節置換膝を対 象にスクワット動作時の動態解析を行い，人工膝関節が示す キネマティクスについて考察した.

\section{2 対象およひ方法}

本研究では, 臨床で応用されている後十字勒帯温存型 (Cruciate-Retaining, CR) が置換されている膝関節を対象と した. 被験者は女性 4 名の 4 膝，平均年齢 $72.3 \pm 7.9$ 歳，平均 体重 $56.5 \pm 2.2 \mathrm{~kg}$ ，および手術からの平均置換期間 $12.8 \pm 7.9$ ケ月であった. 全例支持なく歩行が可能な症例であった.

本研究の動態解析は, FPD で得られたX 線画像と, コンピ ユーターによるシミュレーション像を一致するまで重ね合わ せる手法である ${ }^{1)}$. 大腿骨コンポーネントと脛骨コンポーネン 卜を用いて，本研究の手法による動態解析の検定を行った結 果, 表 1 のような二乗平均平方根偏差 (Root Mean Square Error, RMSE) で 6 自由度を測定できることを確認している. X線撮 影風景を図 1 に示す. X 線撮影は伸展位から被験者が可能な ところまで屈曲し，再び伸展し最伸展位に達するまでを側面 から連続で行った，得られた画像から大腿骨コンポーネント と脛骨コンポーネントの空間位置及び姿勢の 6 自由度をそれ
Tablel Accuracy of motion analysis using image matching

\begin{tabular}{|c|c|c|c|}
\hline RMSE & \multicolumn{2}{|c|}{ Translation [mm] } & rotation [deg] \\
\hline & in-plane & out-of-plane & \\
\hline $\begin{array}{c}\text { femoral } \\
\text { component }\end{array}$ & 0.29 & 0.37 & 0.27 \\
\hline $\begin{array}{c}\text { tibial } \\
\text { component }\end{array}$ & 0.23 & 0.30 & 0.25 \\
\hline
\end{tabular}

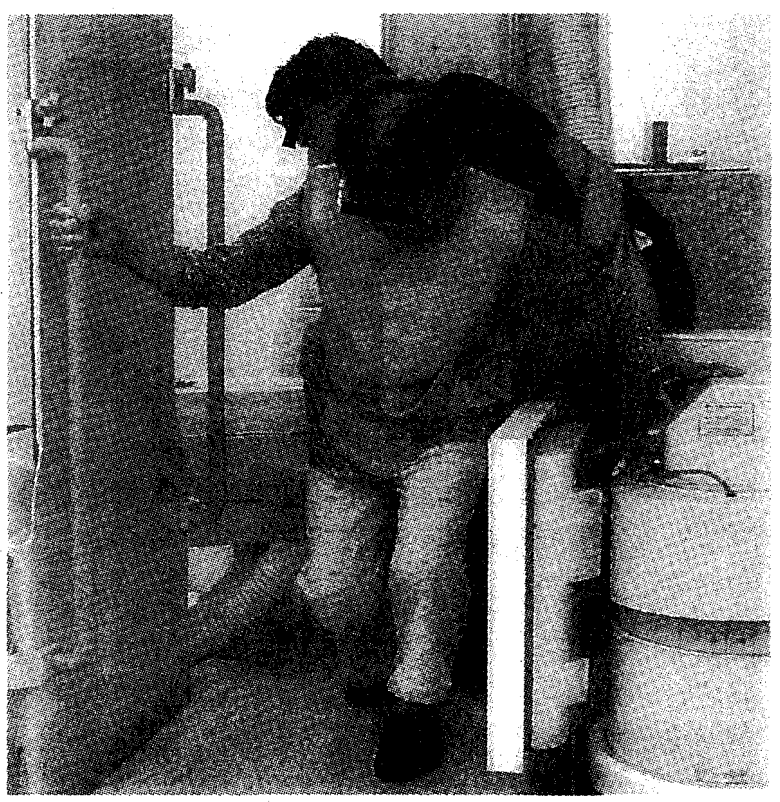

Fig.1 View of squat activity

ぞれ算出し，各コンポーネント間の相対関係を導出した.

\section{3. 桔果およひ考宗}

脛骨コンポーネントから見た大腿骨コンポーネントの 6 自 由度について, 各被験者の变化值を図 2 に示す. グラフの実 線は屈曲，破線は伸展していく様子を表している．横軸は屈 曲角度を示しており, 被験者 $\mathrm{A}, \mathrm{B}$ および C は最大屈曲角が 約 100 度であったのに対し，被験者 Dは約 70 度であった. 内 転/外転のグラフでは，大きな変位は見られなかった，内旋/ 外旋のグラフでは，屈曲時において全被験者共に外旋する傾 向が表れた. 被験者 B は約 75 度から最大屈曲位まで約 4 度内 旋していた. 被験者 $\mathrm{C}$ も若干だが約 90 度から内旋していた。 伸展時においては，全被験者共に内旋する傾向が表れた．下 腿外旋・大腿内旋のスクリューホームムーブメントが確認さ

日本機械学会 [No.07-35] 第18回バイオフロンティア講演会講演論文集（'07. 10.6 6 福岡市) 

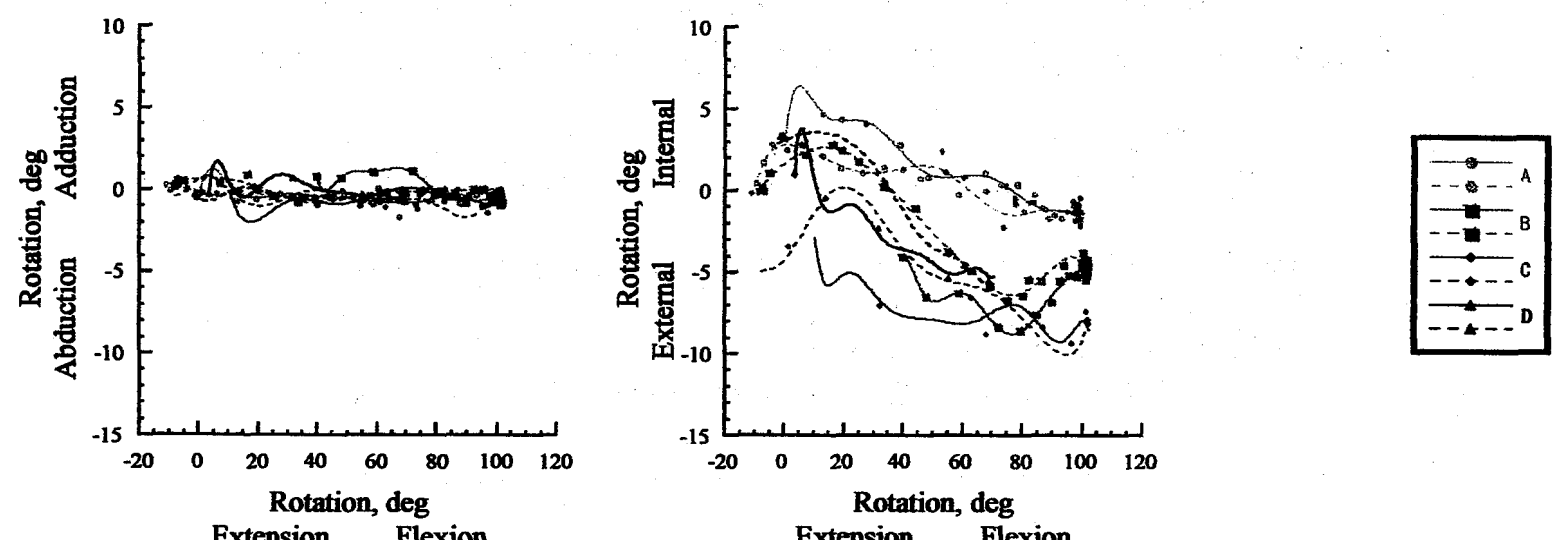

Extension Flexion
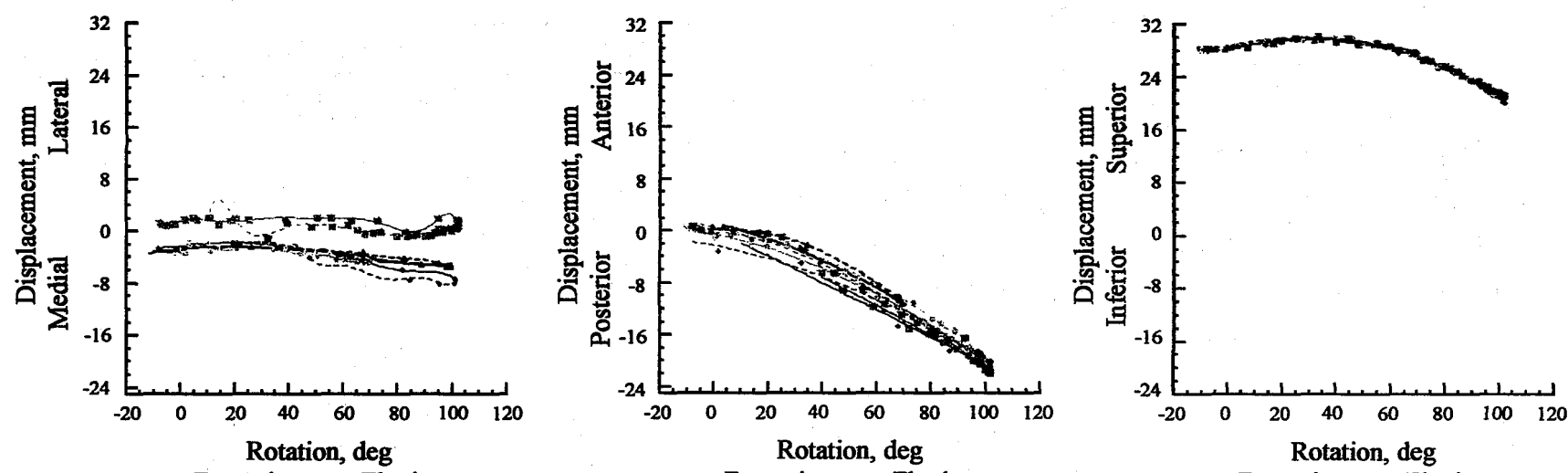

Extension Flexion

Extension

Flexion

Extension Flexion

Fig.2 Pattern of rotation and translation of the femoral component with respect to the tibial component in squat activity

れた. 内側/外側のグラフでは，内転/外転の回転運動の結果 と同様に，大きな変位は見られなかった. 前後方向のグラフ では, 屈曲に伴い後方へ変位した. 全被験者共にロールバッ クが確認された. 被験者 $\mathrm{A} ， \mathrm{~B}$ および C は約 $20 \mathrm{~mm}$ 変位して いたが，被験者 D は約 $12 \mathrm{~mm}$ しか変位していなかった. 被験 者Dの最大屈曲角度である約 70 度付近までの変位量を他の被 験者と比較すると，被験者 D の変位量は小さくなっていた. これは最大屈曲角度が小さいため，他の被験者に比べロール バックが起こりにくく, 後方への変位量が小さくなったと考 えられる．上下方向のグラフでは，全被験者共に同じような 軌跡であった. 内転外転，内側外側および上下方向のグラフ において全被験者であまり差が見られなかったのは，大腿骨 コンポーネントとポリエチレンインサートの形状適合が優先 され，人工関節の形状に沿った動態になったことが考えられ る.

屈曲角度の小さかった被験者 D のポリエチレンインサー トに対する大腿骨コンポーネントの最接近点の軌跡を図 3 に 示す. 伸展位から最大屈曲位までを0-100\%とし, 実線を屈曲, 破線を伸展とした. ポリエチレンインサート顆間部での接触 が見られ，メディアルピボットでの大きな回旋運動が確認で きた. 屈曲角度が大きかった被験者 $\mathrm{A} ， \mathrm{~B}$ およびCにおいて は，顆間部と辺縁部付近で最接近点は集中しており，大きな 変位は確認できなかった. 被験者 D の屈曲角度が小さかった 原因として，図 3 のような軌跡が確認できたことから，人工 膝関節が片顆接触の不安定な動態となり屈曲が制限されたた めと考えられる.



Fig.3 Maximum approach point on polyethylene insert in a squat activity

\section{4. 結言}

FPDから出力される医用画像と MM法を応用することによ り，スクワット動作時における人工関節置換膝の動態解析を 行った. CR 型の人工滕関節は形状に沿った動態になりやすい ことが確認された. 今後さらに多くの症例を解析することで, スクワット動作動態パターンが確認できる. 日常生活を同じ 条件での動態解析は，次世代人工膝関節の設計に有用な情報 を与える他，臨床において患者個々の診断（生活指導や歩行 上の注意等）に応用することが期待される.

\section{参考文献}

1) 下戸健, 他,バイオメカニズム学会誌, 28(4):213-220, 2004 